\title{
The grand challenge of physiology: to integrate function from molecules to man
}

\section{George E. Billman*}

Ohio State University, Columbus, $\mathrm{OH}$, USA

${ }^{*}$ Correspondence: billman.1@osu.edu

“...All the kings' horses and all the kings' men

Could not put Humpty Dumpty together again"

Traditional English Nursery Rhythm (earliest published version 1803) (Opie and Opie, 1997).

The term physiology was first introduced by Jean Francois Fernel (ca. 1497-1558) in 1542 [De Naturali Parte Medicinae (on the natural part of medicine)] as the study of the function of the healthy body as distinguished from pathology, the study of disease (Hall, 1975). William Harvey (1578-1657) is often regarded as the father of modern physiology as he was the first individual to use carefully designed human and animal experiments to establish the function of a major bodily organ system with his description of the circulation of the blood. This application of physiology is illustrated in the following brief quotation from his seminal publication "Exercitatio Anatomica De Motu Cordis et De Circulatione Sanguinis in Animalibus" 1628 (Anatomical exercises on the motion of the heart and the circulation of blood in living creatures, first English translation 1653):

\begin{abstract}
"It has been shown by reason and experiment that blood by the beat of the ventricles flows through the lungs and is pumped to the whole body ... the blood in the animal body moves around in a circle continuously, and ... the action or function of the heart is to accomplish this pumping. This is the only reason for the motion and beat of the heart."'(Harvey, 1995).
\end{abstract}

Over the ensuing centuries, the concept of physiology has evolved and a central tenet has emerged that unites the various sub-disciplines of physiology: the quest to understand how the various components of the organism work together to maintain a healthy state. It is only by understanding normal bodily function that the disruptions that lead to disease can be determined and

ultimately corrected so as to restore the healthy state. The French Physiologist, Claude Bernard (1813-1878) was perhaps the first to appreciate that living systems possess an internal stability that buffers and protects the organism against a constantly changing external environment. He recognized that the body possesses mechanisms that operate in a coordinated fashion to maintain a relatively constant temperature and blood glucose concentration and this internal stability was vital for the health of the organism. He concluded that: " $L a$ fixité du milieu intérieur est la condition de la vie libre, independante" (Bernard, 1865). The fixity (i.e., constancy) of the internal environment is the condition for the free, independent life]. This concept of a constant internal environment (milieu intérieur) was expanded by the American Physiologist, Walter Cannon (1871-1945) who coined the term homeostasis (Greek for staying the same) to describe the selfregulating processes by which a biological system maintains stability while adjusting to changing environmental conditions. As he explained in the following quote from his highly influential monograph, "The Wisdom of the Body", published in 1932:

\begin{abstract}
"The coordinated physiological processes which maintain most of the steady states in the organisms are so complex and peculiar to living beings - involving, as they may, the brain and nerves, the heart, lung, kidneys and spleen, all working cooperatively - that I have suggested a special designation for these states, homeostasis. The word does not imply, something set and immobile, a stagnation. It means a condition - a condition which may vary, but is relatively constant." (Cannon, 1963).
\end{abstract}

As emphasized by Cannon, homeostasis is not static; it is, rather, a dynamic selfadjusting system that maintains viability in the face of changing environmental demands. This "constancy" is largely maintained by the often complex interaction of multiple negative feedback systems. Thus, from its inception physiological investigations have been directed toward understanding the organism (be it microbe, plant, animal or man) as a single functional entity.

In recent, years, reductionist (attempts to explain the nature of complex phenomena by reducing them to a set of ever smaller and simpler components; the view that the whole is merely the sum of its parts), rather than holistic approaches have become dominant, not only in physiology, but in science in general. The earliest glimmerings of reductionist thought can be found in the surviving fragmentary writings of Thales and other pre-Socratic Greek philosophers who speculated that all matter was composed of various combinations of four key elements: earth, air, fire and water (Hall, 1975). The pinnacle of Greek reductionism is found in the work of Leucippus and his student Democritus who proposed that all things consist of an infinitely large number of indivisibly small particles that they called atoms (Hall, 1975). The modern application of reductionism in science can be traced to Francis Bacon (1561-1620) who incorporated it as a central component, along with inductive reasoning, in his new method (Novum Organum 1620, as opposed to Aristotle's Organon a treatise on logic and syllogism, i.e., deductive reasoning) (Bacon, 2000) for the attainment of knowledge in natural philosophy, what has subsequently become known as the scientific method.

There can be no denying the power of this approach. In only a few decades after DNA was identified as the molecule of inheritance, its sequence of the some 3 billion base pairs has been mapped for man and other species, the genetic "code" for protein synthesis has been broken, and between 20,000 and 25,000 human genes that regulate a multitude of proteins have been determined. Humpty Dumpty quite literally has been smashed into a billion pieces. 
The grand challenge faced by contemporary physiology in this post-genomic era is to integrate and to translate this deluge of information obtained in vitro into a coherent understanding of function in vivo. Although a machine may consist of many parts, the parts in isolation do not make the machine. In an analogous fashion, while men are made of molecules, molecules are not men. The concept of one gene, one protein, one function is woefully inadequate to explain the dazzling complexity and startling beauty of the living organism - the intricate dance of homeostatic mechanisms necessary for a "free and independent life." A sequence of base pairs in the DNA molecule can no more explain the complexities of life than a series of $1 \mathrm{~s}$ and $0 \mathrm{~s}$ on a compact disc recording can explain the emotional response to music (Noble, 2006). Man and other organisms are not mere vehicles for the perpetuation of genes, selfish or otherwise. It is time for physiology to return to its roots and to employ more holistic systems approaches in order to put Humpty Dumpty back together again.
A second, and by no means less important, challenge will be train the next generation of scholars to perform the integrative studies in whole animals that are the pre-requisite for clinical applications. Unfortunately, there has been a progressive decline in the number of integrative physiology training programs, resulting in a paucity of individuals with the skill sets necessary for whole animal in vivo experimentation. It remains an open question as to whether a sufficient number of suitably trained investigators will be available to meet the grand challenge: to integrate function from molecules to man.

It is a goal of the Frontiers in Physiology family of Journals to provide a forum for the free exchange of ideas and to foster an international community of researchers to meet these challenges.

\section{REFERENCES}

Bacon, F. (2000). The New Organon, eds L. Jardine and M. Silverstone (New York, NY: Cambridge University Press).
Bernard, C. (1865). Introduction à l'étude de la Médecine Expérimentale. Paris: J. B. Baillière et Fils. (English Translation by Greene H. C., Dover Publications, Inc. NY, 1957).

Cannon, W. B. (1963). The Wisdom of the Body. Revised and Enlarged edition (first published 1939). New York, NY: W. W. Norton \& Co., Inc.

Hall, T. S. (1975). History of General Physiology: 600B.C to A.D. 1900, Vol. I from Pre-Socratic Times to the Enlightenment. Chicago: University of Chicago Press.

Harvey, W. (1995). The Anatomical Exercises: De Motu Cordis and De Circulatione Saguinis in English Translation, ed. G. Keynes (NY: Dover Publications, Inc.).

Noble, D. (2006). The Music of Life: Biology Beyond Genes. New York, NY: Oxford University Press.

Opie, I., and Opie, P. (eds) (1997). The Oxford Dictionary of Nursery Rhymes. New York, NY: Oxford University Press.

Received:07 April 2010; accepted:07 April 2010; published online: 27 April 2010.

Citation: Billman GE (2010) The grand challenge of physiology: to integrate function from molecules to man. Front. Physio. 1:5. doi: 10.3389/fphys.2010.00005

Copyright (c) 2010 Billman. This is an open-access article subject to an exclusive license agreement between the authors and the Frontiers Research Foundation, which permits unrestricted use, distribution, and reproduction in any medium, provided the original authors and source are credited. 